Cambridge in 1921 as a research student under the late Sir Frederick Gowland Hopkins. These were the pioneering days of enzymology, which saw its development into an exact science, and it was to this field that Prof. Quastel made some of his most important contributions. His exhaustive studies of the resting metabolism of bacteria, which form the basis of present-day microbiological techniques, led to the characterization of new enzyme systems, while his discovery of the specific competitive inhibitors of enzyme action has had the widest application in this field. Prof. Quastel's fundamental contribution at this time was his work on the reversibility of dehydro. genase action. Working with succinic dehydrogenase, he showed that the change in free energy determined from the observed equilibrium point agreed closely with the value calculated from thermal data.

In 1929 Prof. Quastel was appointed director of research to the Cardiff City Mental Hospital, where he investigated the biochemical aspects of mental disease. Fruitful results arising from the integration of clinical and research aspects of these problems has encouraged the development of similar units elsewhere. Following the outbreak of war, Prof. Quastel accepted in 1941 the invitation of the Agricultural Research Council to organise a Unit of Soil Biochemistry at Rothamsted. In this field his work showed the same originality of outlook that was apparent in his earlier work. By repeated percolations of a small quantity of soil by an aqueous solution in a closed circuit and periodic addition of reagents or removal of samples for analysis, detailed qualitative data on soil metabolism, in particular nitrogen metabolism, were obtained. Prof. Quastel was awarded the Meldola Medal in 1927, and was elected a fellow of the Royal Society in 1940. One can with confidence anticipate the development, under his guidance, of a vigorous school of cellular metabolism at MeGill University.

\section{Institute of Fuel : New Building}

THE Institute of Fuel was founded in 1927, soon after the general strike in Britain-a national disaster which started much thought about fuel problems. In several directions action was taken to establish new technical organisations which eventually, by processes of mutual attraction or absorption, led to the foundation of this Institute of Fuel. After ten years or so of useful work, the Institute gathered together about 1,000 members. Then came the War to provide new tasks and opportunities for service which the staff and members were able and ready to seize. As a result, its roll of members has since increased threefold. Regional sections have been formed, schemes of education have been launched, including examinations to qualify for membership, and in 1946 a petition for incorporation by Royal Charter was granted. This year, in order to carry on its work more effectively, the Institute has acquired permanent headquarters at 18 Devonshire Street, London, W.1. It has issued an appeal to all who are interested to contribute sums in support. Already about $£ 8,000$ has been received. Cheques should be addressed to the Secretary, Institute of Fuel, 18 Devonshire Street, London, W.I.

\section{Civil Aircraft Research}

Ir has been announced that the terms of reference of the Civil Aircraft Research Committee of the Aeronautical Research Council are: "To consider the basic research problems arising from the evolution and operation of civil aircraft, having regard, inter alia, to the probable requirements of the operators; to recommend periodically to the Council programmes of research; and to report to the Aeronautical Research Council". The members are Prof. A. A. Hall (chairman), Prof. A. R. Collar, Dr. T. E. Easterfield, Prof. S. Goldstein, Major F. M. Green, Sir Melville Jones, Prof. R. L. Lickley, Dr. H. R. Ricardo, Mr. P. A. Sheppard, Prof. G. Temple, and representatives of the Ministry of Supply, the Ministry of Civil Aviation, the National Physical Laboratory, and the three airways corporations.

\section{Zoological Society of Bengal}

THE Government of India has recently decided to transfer the office of the Zoological Survey of India from Calcutta to Delhi. As a result, the zoologists of Bengal will be deprived of the use of the only zoological library in that part of the country. In order to meet this difficulty, the Zoological Society of Bengal is issuing an appeal for assistance in the hope that zoologists will present them with reprints of their papers and put the Society on their mailing lists. The Zoological Society of Bengal was only founded last year, but the annual report for 1946 shows that already 294 members have been enrolled and various meetings held. Among the speakers has been Prof. H. Munro Fox, one of the British delegates to the Indian Science Congress Association. The Society proposes to issue monographs of typical Indian animals and also a bulletin dealing with simple zoological laboratory technique. It also hopes to publish a journal devoted to zoological research in India. The president is Prof. H. K. J. Mookerjee, and secretary, Dr. S. P. Ray Chaudhuri. The Society's address is 35 Ballygunge Circular Road, Calcutta.

\section{A Science Journal for South Africa}

At a meeting of the South African Association for the Advancement of Science, held in Johannesburg on May 16, it was resolved that the Association should commence publication at the earliest possible date of a monthly periodical covering the whole field of science. The venture will be paid for by the Association and will not be in any way a profit-making organisation; it is intended that the journal should be distributed free to all members of the Association, and that it may later be made available for sale to the public. It is hoped to present leading articles, reviews of books, and articles of a general character, and to devote three or four pages to "Letters to the Editor", a section which it is hoped will become a forum for scientific discussion. It is intended that articles, etc., should be of such a nature as to appeal to scientific workers in fields other than those of their own speciality, and it is believed there will be sufficient popular material to appeal to the more general reader of scientific interests. The journal will be produced by the Association, the honorary editor being Dr. H. B. S. Cooke, of the University of the Witwatersrand.

\section{American Institute of Physics}

The January issue of the Review of Scientific Instruments contains an important announcement concerning the reorganisation of the American Institute of Physics. The five societies, the American Physical Society, the Optical Society of America, the Acoustical Society of America, the Society of Rheology and the Amorican Association of Physics 
Teachers, which are members of the Institute, have unanimously ratified a change in the constitution under which members of the societies automatically become individual members, without additional subscriptions, of the Institute, thus creating a large unified professional body of physicists. The amended constitution and the new rules are printed in full. No change is made in the organisation, functions or activities of the member societies; but the way is opened for all persons interested in physies to play, individually, a greater part in the affairs and interests of physics, where these are of common concern and can prosper best by the combined active support of all. Provision is made under the new constitution for others, not members of the participating societies, to become associate members of the Institute.

It is intended, when sufficient finance is available, to establish an official monthly journal of the Institute, to be sent without additional charge to all members of the Institute. This journal will contain news about physicists, their meetings, work and other activities, and about similar features in related fields ; information about the action of government and other non-physical agencies affecting physics; articles and letters expressing views of physicists on problems of general importance; references to current literature in physics; book reviews, etc. When this journal, for which the title Physics has been suggested, appears, the Review of Scientific Instruments will revert to a journal devoted exclusively to the science of instruments. It is hoped that associate members, who will be recruited from the very large number of school teachers, students and others who have graduated in physics and thus have an interest in the subject, will be encouraged through the medium of the new journal to become members of one or more of the participating societies.

\section{Fresh Water Biology in Italy}

Founded in 1939 by private endowment, the Istituto Italiano di Idrobiologia de Marchi, at Pallanza (Province Novara), is scarcely known abroad. It is situated on the north shore of Lake Maggiore in one of the most suitable and beautiful sites for carrying out research and enjoying the surroundings. Its excellent equipment for field and laboratory research, its spacious accommodation and its sub-station-in a beautiful villa on Lake Comoprovide full facilities for any kind of limnological investigation on the great lakes at the foot of the Alps; and a number of smaller lakes all the way up the slopes of the Alps are within easy reach. The main activities of the staff are freshwater ecology, systematics and genetics, a series of papers having already appeared as the Institute's Memorie. Free lodging and free laboratory facilities are offered to foreign guests (up to five at one time). Other facilities may be arranged for by agreement with the director, Dr. E. Baldi. Pallanza is easily reached from either of the two international railways, the Simplon and the St. Gotthard.

\section{Radiolocation Convention Papers}

As already mentioned in Nature (February 1, p. 174), the Proceedings of the Radiolocation Convention held at the Institution of Electrical Engineers in 1946 are being published as a series of special numbers of Part 3 of the Journal of the Institution. Five such numbers have now been issued, and reference has already been made to the first two. No. 3 contains two papers dealing with some aspects of the propagation of radio waves overland in the wave-length range $10 \mathrm{~cm} .-10 \mathrm{~m}$. ; and nine papers describing the development for radar purposes of special aerial systems for use in the metre band of wave-lengths between $\mathbf{1 . 5}$ and 15 metres. The corresponding developments in aerial systems for centimetre wave-lengths are dealt with in a series of six papers forming part of the fourth number (Vol. 93, Part III A, No. 4) of this special publication.

Since it is in the centimetre range of wave-lengths that the wave guide replaces wire circuits and cables for connexions between different parts of the radiofrequency equipment and between the equipment and the aerial system, it is natural to find the twelve papers on wave guides also in this fourth special number. These papers deal with some of the problems involved in design and in the application of waveguide technique to very short wave radio equipment. The fifth number (Vol. 93, Part III A, No. 5) contains five papers on cathode-ray tubes and twelve on valves. In the first place, these describe some of the advances made in the use of cathode-ray tubes, with special screens in many cases, for radar display purposes. The second series of papers provides a comprehensive record of the special valve development conducted in Great Britain during the War, ranging from triodes for very short waves, the con. ception and development of that important device, the resonant cavity magnetron, to the high-power pulsed magnetron and the velocity-modulation reflexion oscillator. Since a crystal detector, now termed a crystal valve, is an essential part of all centimetre wave radio receivers, a paper on this subject is included in this particular number of the publication.

\section{National Museum of Wales}

THE report for 1946 of the National Museum of Wales again exhibits that activity of service (external as well as internal) which is conformable with the purport of a great institution. In this report the acquisition of St. Fagans Castle and grounds for use as a Welsh folk museum is fully discusscd; plans for its future organisation are outlined, and it is stated that part of the new folk museum and grounds will be ope ed to the public during the present year. An interesting development, and one which would seem to offer scope for the future, was the circulation in 1946 of a travelling exhibition of the Llyn Cerrig and Valley aerodrome finds-finds which had "excited so much interest throughout the Principality and especially in the island" (Anglesey). The exhibits were first set up at Holyhead, where an official lecture was given, then at Llangefni, and finally at Bangor. At each of the first two places it remained four weeks, and at Bangor for a longer period. It is of further interest that this movement was made in response to a request from the Anglesey Education Committee and the Committee of the Museum of Welsh Antiquities at the University College of North Wales, Bangor.

Departmental reports are primarily concerned with routine work, and the work of reorganisation which necessarily follows the return of collections from war-time storage. During the year some of the reference collections were again available for use. Those who believe in the practical educational value of museums under adequate schemes of organisation will be interested in the development regarding the proposed schools service mentioned on p. 20 of the report. This states that the Parliamentary Secretary to the Ministry of Education, Mr. D. R. Hardman, 